\title{
Current Research: Preliminary Survey of the Eastern Half of the Boxed Spring Site (41UR30)
}

Cambria Haley

Department of Anthropology, Wichita State University

Crystal A. Dozier

Department of Anthropology, Wichita State University

Follow this and additional works at: https://scholarworks.sfasu.edu/ita

Part of the American Material Culture Commons, Archaeological Anthropology Commons, Environmental Studies Commons, Other American Studies Commons, Other Arts and Humanities Commons, Other History of Art, Architecture, and Archaeology Commons, and the United States History Commons

Tell us how this article helped you.

This Article is brought to you for free and open access by the Center for Regional Heritage Research at SFA ScholarWorks. It has been accepted for inclusion in Index of Texas Archaeology: Open Access Gray Literature from the Lone Star State by an authorized editor of SFA ScholarWorks. For more information, please contact cdsscholarworks@sfasu.edu. 
Current Research: Preliminary Survey of the Eastern Half of the Boxed Spring Site (41UR30)

\section{Creative Commons License}

\section{(c) (1) ()}

This work is licensed under a Creative Commons Attribution-NonCommercial 4.0 International License 


\title{
Current Research: Preliminary Survey of the Eastern Half of the Boxed Spring Site (41UR30)
}

\author{
Cambria Haley and Crystal A. Dozier \\ Department of Anthropology, Wichita State University
}

The Boxed Springs site (41UR30) is an Early Caddo

site located in East Texas near the Sabine River.

This site covers roughly 15.6 acres and contained at least four mounds, middens, and an extended cemetery (Perttula 2011) (Figures 1 and 2). The site's location has been known since the late 1950s, with a series of unconnected avocational and professional archaeological investigations as well as unfortunate looting (Perttula 2011). As one of the few Early Caddo sites in Texas that contain multiple mounds (Perttula 2012, 2017), the Boxed Springs site is poised to provide great insight into Early Caddo mound construction technologies, settlement patterns, subsistence strategies, and trade and exchange.

Professional archaeological investigation at the site, however, has been limited. Avocational excavations were conducted by Buddy C. Jones in 1957 and 1961 and Sam Whiteside, a member of the East Texas Archeological Society, in 1962. Jones's excavations were limited to Mounds C and D; Whiteside excavated into Mound A (Perttula and Wilson 2000). A map of the site was produced by Dr. Dee Ann Story who visited the site in 1982 but did not excavate. Perttula has this map redrawn by Sandra Hannum (see Figure 1), as well as Jones and Whitesides' notes, although information from avocational and visiting archaeologists did not provide scale in order to later locate these features. We utilize Story's designations for the mounds in this report.

In 1988, the site was visited briefly from a crew from the University of North Texas and shortly thereafter at least 150 individuals were disinterred in a looting episode from a cemetery context at the site (Perttula 2011:16; Perttula and Walters 2015). In 2010, a volunteer crew provided the most thorough investigation of the site, including shovel tests, limited unit excavation, and ground penetrating radar, that have provided the best resolution data thus far (Perttula 2011). This survey, however, was limited to the western half of

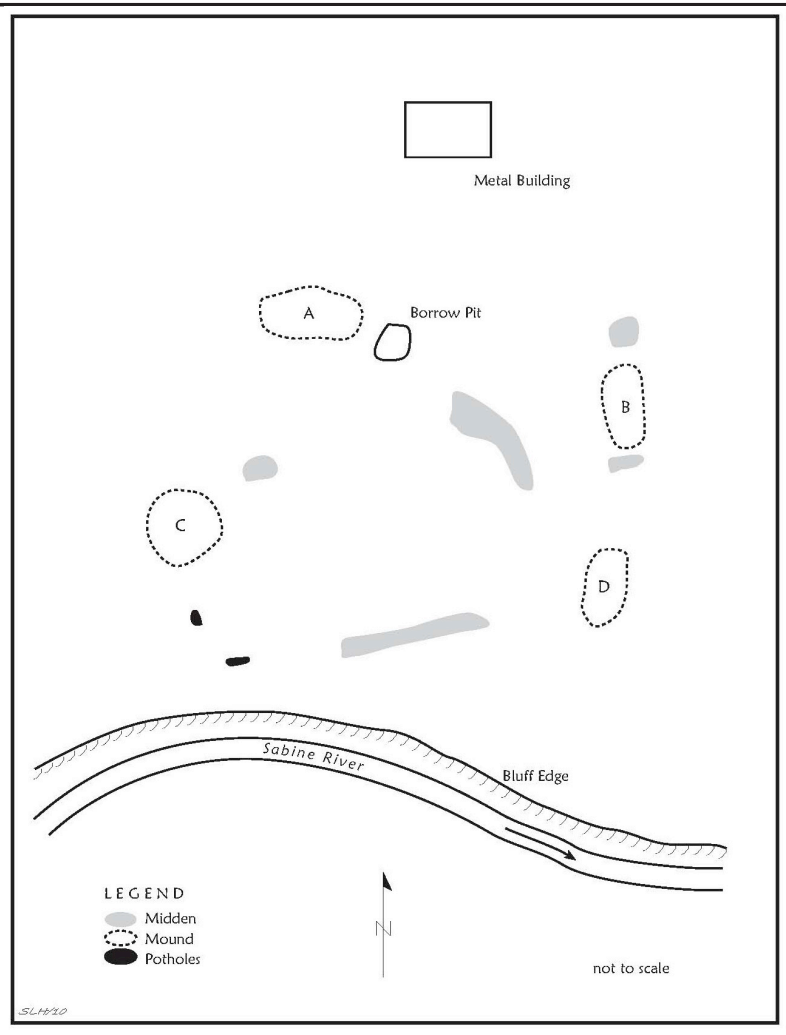

Figure 1. Map of the Boxed Springs site by Dee Ann Story in 1982, and as adapted in Perttula (2011:17).

the site due to private landowner access. No professional survey of the eastern half of the site has been previously conducted and many alterations have been made to the landscape due to the construction of several buildings and ponds on the property in the 2000s.

Since the 2010 survey, the eastern half of the site has acquired new landowners. From the Story map, the metal building still stands, and it is safe to assume that locations to the east of the building are now located on the eastern half of the site, which should include two mounds (Mounds B and D) and several midden areas. In the interest of protecting and promoting the understanding of the Boxed Springs Site, the new landowners invited archaeologists from Wichita State 

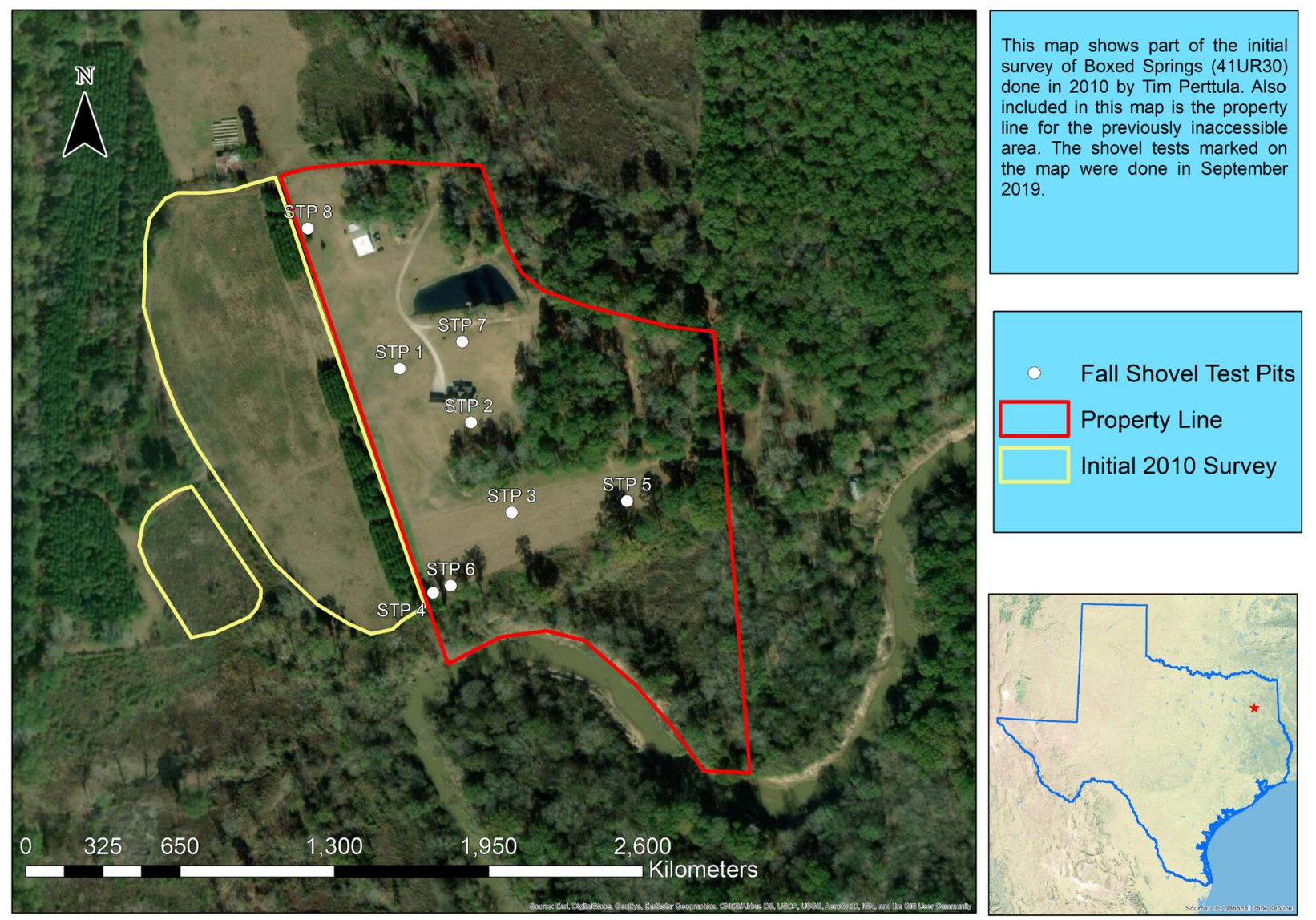

Figure 2. Map of surveyed area at the Boxed Springs site.

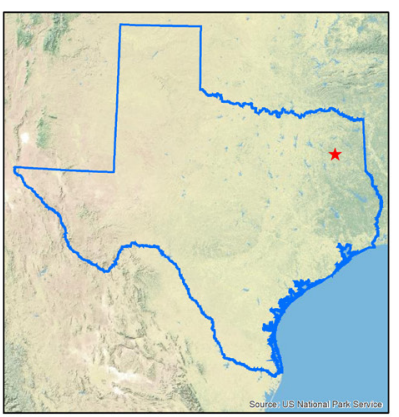

University to investigate the property. Over two days in September 2019, a preliminary survey of this new property was conducted.

The goals of the present preliminary survey were simple: (1) to determine the likelihood to recover archaeological materials related to the Early Caddo occupation of Boxed Springs and (2) to assess the presence and/or condition of the proposed two mounds on the property.

Limited non-probabilistic shovel test pitting was chosen to investigate areas previously identified as likely containing mound or midden areas. Ground surface visibility was zero due to a thick low-cut carpet of grasses, limiting the pedestrian surface survey as a means to recover artifacts. Heavy ground cover and modern surface alterations meant that mound locations were not distinct from the rest of the landscape. The survey consisted of eight shovel test pits (STP) across the property (see Figure 2). These pits were $40 \mathrm{~cm}$ diameter, dug in 10-centimeter levels to up to 1 meter in depth or terminated at the contact with sterile B-horizon sediment. Levels were screened through $1 / 4$-inch mesh. Only diagnostic artifacts or artifacts related to mound construction were collected, such as artifacts found in mound fill or diagnostic ceramics or projectile points. In total, the artifacts from only two shovel test pits were retained. All other artifacts were recorded, photographed, and returned to the STP. Profiles of all the pits were recorded and photographed.

The majority of STP contained cultural materials consistent with an indigenous Caddo occupation. STP 1, 2, and 7 were placed to attempt to locate Mound B; STP 3 and 5 were placed to locate Mound D; STP 4 and 6 were placed to locate a proposed midden area, and STP 8 was included to help establish the extent of cultural material across the northern portion of the property. Only STP 1 and 8 had no cultural materials (Table 1).

Across the site, no cultural material was found beyond $85 \mathrm{~cm}$ below the surface. The common soil profile of the site matched Perttula's findings (2011), with a sandy or silty loam A-horizon followed by a 


\begin{tabular}{|l|l|l|}
\hline $\begin{array}{l}\text { Shovel } \\
\text { Test Pit }\end{array}$ & $\begin{array}{l}\text { Depth } \\
\mathbf{c} \\
\text { bs })\end{array}$ & Cultural Material \\
\hline STP 1 & $0-50$ & No Cultural Material \\
\hline STP 2 & $0-20$ & 1 cultural shatter, slag throughout \\
\hline STP 2 & $20-40$ & 1 brown glass \\
\hline STP 3 & $20-40$ & 1 flake and 1 plain sherd \\
\hline STP 3 & $40-50$ & 1 flake and 1 plain sherd \\
\hline STP 4 & $0-75$ & 1 sherd, 1 decorated sherd, 1 piece petrified wood, 1 \\
fire-cracked rock, 2 bones
\end{tabular}

Table 1. Artifacts recovered in shovel test pits at the Boxed Springs site.

silty clay loam B-horizon. Small $\left(<3 \mathrm{~cm}^{2}\right)$ undecorated sherds were the most common artifact recovered, followed by lithic flakes. Two notable discoveries were made in this small survey: (1) a diagnostic decorated sherd consistent in style with the Early Caddo occupation, and (2) a STP 7 soil profile that is indicative of Mound B deposits.

One decorated sherd was recovered in STP 4, which was placed near a proposed midden location (Figure 3). The piece has closely incised lines at the rim and a single line of fingernail punctations. The fine grog tempering is consistent with either Weches Fingernail Impressed or Kiam Incised, both Early Caddo period ceramic types (Perttula 2004; Perttula et al. 1995; Suhm and Krieger 1954). This sherd was retained for future study and comparison.

STP 7 provided a completely unique soil profile. The top 30 centimeters contained a heavily mottled silty loam that contained frequent pieces of charcoal, burnt sandstone, and burnt soil. One clear piece of historic glass was found in this level. The following 70 centimeters, however, was a fine, remarkably homogenous, light gray silty sand. The grain and consistency of the sediment was clearly anthropomorphic, as this sand was not found in any other part of the site and this part of the site is far removed from any fluvial action from the Sabine River. Within this fill, three small lithic flakes were recovered up to 85 centimeters below the surface. This sediment

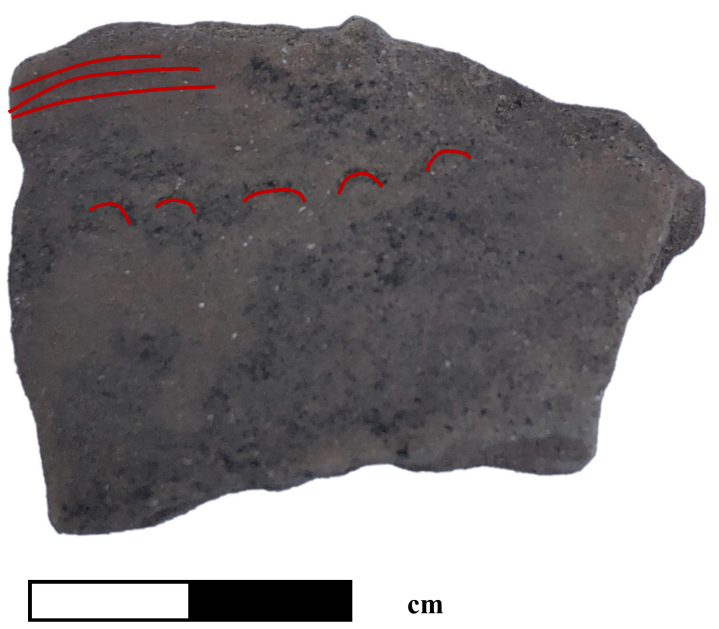

Figure 3. Image of Early Caddo sherd from STP 4. Decorations marked in red for clarity.

continued past 98 centimeters below the surface when the STP had to be terminated. These flakes were collected for further study. The location of this feature in STP 7 broadly matches the location of Mound B.

Both of the goals for this initial survey were partially met. An Early Caddo component in the eastern part of the site was confirmed by the recovery of a single diagnostic sherd, but as the only diagnostic artifact recovered in our very limited work, many questions remain concerning the occupation history of the site. The decorated sherd matches either the Weches Fingernail Impressed or Kiam Incised types, and sherds of both types were found in the 2010 excavations as well as the 1957 investigations, presumably from mound contexts. No radiocarbon samples were taken from this initial survey, and future study of the site will hopefully be able to obtain more data on the precise timing of the site's founding, occupation, use, and abandonment.

The presence of one of the mounds (Mound B) was located due to the obvious mound fill profile seen in STP 7. However, more work will need to be done in order to understand the extent of the mound in terms of its footprint, height, possible alterations, and possible uses. From the one shovel test pit, it is unclear if the top 30 centimeters are part of the mound construction or due to the historic building of the house and stock pond as shown in Figure 2. Whiteside noted that Mound B was a sand fill mound, further supporting our identification of the area of STP 7 as being in Mound B, but he did 
not further document the mound. As the only mound at the site to not have received documented avocational excavations, it is especially important to document and preserve Mound B with as little damage as possible.

While Mound B was likely located, Mound D was not identified from this initial survey. Mound D had been excavated in 1957 with a $10 \times 5$ foot trench - it apparently stood one meter tall with multiple mound fills (Perttula 2011:279); in the Whiteside excavation, Mound D was recorded as only $45 \mathrm{~cm}$ tall over a prepared clay floor. Similarly, in the survey of the western half of the site by Perttula and crew, the location of Mound A, which had been damaged by both looters and Sam Whiteside's 1962 excavations, was not apparent in their 2010 survey (Perttula 2011:2).

There is much potential for archaeological research and data recovery at the Boxed Springs site. This small initial survey confirmed an Early Caddo presence in the eastern part of the site and the findings provide clear direction for future research to investigate the mounds and residential features at Boxed Springs.

\section{References Cited}

Perttula, T. K.

2004 The Prehistoric and Caddoan Archeology of the Northeast Texas Pineywoods. In The Prehistory of Texas, edited by T. K. Perttula, pp. 370-407. Texas A\&M University Press, College Station

2012 The Archaeology of the Caddo in Southwest Arkansas, Northwest Louisiana, Eastern Oklahoma, and East Texas: An Introduction to the Volume. In The Archaeology of the Caddo, edited by T. K. Perttula and C. P. Walker, pp. 1-26. University of Nebraska Press, Lincoln.

2017 Caddo Landscapes in the East Texas Forests.

Oxbow Books, Oxford, England.
Perttula, T. K. (editor)

2011 Archaeological and Archaeogeophysical Investigations at an Early Caddo Mound Center in the Sabine River Basin of East Texas. Special Publication 15. Friends of Northeast Texas Archaeology, Pittsburg and Austin.

Perttula, T. K. and M. Walters

2015 Documentation of Ceramic Vessels from an Early Caddo Period Feature at the Boxed Spring Site (41UR30) Site, Upshur County, Texas. Journal of Northeast Texas Archaeology 57:31-43.

Perttula, T. K. and D. Wilson

2000 An Early Caddo Period Cremation from the Boxed Spring Site (41UR30) in Upshur County, Texas, and a Report on Previous Archaeological Investigations. Journal of Northeast Texas Archaeology 12:31-71.

Perttula, T. K., M. R. Miller, R. A. Ricklis, D. J. Prikryl, and C. Lintz

1995 Prehistoric and Historic Aboriginal Ceramics in Texas. Bulletin of the Texas Archeological Society $66: 175-235$.

Suhm, D. A. and A. D. Krieger, with contributions by E. B. Jelks

1954 An Introductory Handbook of Texas Archeology. Bulletin of the Texas Archeological Society 25:1562. 